\title{
The Fungus present in Pellia epiphylla, (L.) Corda.
}

BY

\author{
W. F. F. RIDLER. \\ With eight Figures in the Text.
}

W ATERIAL of Pellia epiphylla gathered from Leigh Woods, Somerset, contains an account of an investigation of the life-history of the funguswhich always proved to be present in material collected from the locality mentioned above-as well as in material obtained from the Royal Horticultural Society's garden at Wisley, Surrey, where the plants had developed on humus at the base of an Osmunda regalis; from a wood at Pensford, near Bristol, where it grew on a soil mainly composed of clay; from the Jardin Botanique de l'État at Brussels-this material was removed from the 'Rouge Cloître' near Brussels in I9I 4 and since that date had been cultivated in a cold greenhouse; from Cromer, Norfolk; Worcester ; Leeds; Belfast; and the Forêt des Soignes, Belgium. In the last case it was growing on sandy soil. With the exception noted above, the material was always from clay soils containing varying amounts of humus. No plant of Pellia epiphylla has been found in which fungal infection was entirely absent.

\section{Historical Notes.}

Examples have been noted by various authors of species of Musci being infested by fungal mycelia. Thus Cooke (1889) recorded the presence of Cladosporium epibryum on certain moss plants without giving exact indications of the host on which they occurred. Britton (1911) obtained the list of mosses which are host species for this fungus from Massee, to whom they had been sent by Cooke. This list consisted of Ulota phyllantha, Brid., Grimmia ovata, W. and M., Grimmia Doniana, Sm., Encalypta rhabdocarpa, Schwgr., Bartramia pomiformis, Hedw., Hypnum megaptilum, Sull., Fabronia andina, Mitt., and Bartramia Potosica, Mont. In 19 II Györffy noted the presence of Cladosporium herbarum, (Pers.) Link., on capsules of Buxbaumia veridis, Brid. Dunham (1916) found the spores of Pestalozzia present in a capsule of Funaria hygrometrica, var. patula, Br. and Sch. Fitzpatrick (1918) published a detailed account of the

[Annals of Botany, Vol. XXXVII. No. CXLII. April, 1922.] 
life-history and parasitism of Eocronartium muscicola, (Fries) Fitzpatrick, which he had found to occur chiefly on Climacium americamum, but which had also been collected on Anomodon rostratus, Leskea obscura, L. polyantha, Thuidium delicatulum, T. minutulum, Amblystegium serpens, A. varium, A. riparium, Brachythecium oxycladon, Climacium dendroides, C. Kindbergii, Entodon seductrix, Hypnum chrysophyllum, Plagiothecium Muellerianum, and Pylaisia intricata.

Servattaz (1913) recorded the occurrence of Oospora in connexion with the protonema of Phascum cuspidatum, Schreb.

Schimper (1858) and Warnstorff (1886) had observed the presence of numerous small spores in capsules of Sphagnum, among the spores of the moss. These they considered to be male spores. Nawaschin (I 892) proved that these so-called 'microspores' were in reality spores of the fungus Tilletia sphagni. Warnstorff noted similar spores in capsules of Pallavicinia Lyellii, (Hook.) Gray. Cavers confirmed this observation (1903), and noted that the spores were abstricted from hyphae of the fungus and were therefore true conidia.

The occurrence of fungal hyphae in the tissues of Hepaticae was first described by Leitgeb, who observed that young sporogonia of Ptilidium ciliare, (L.) Hampe, were frequently infested by the mycelium of a fungus. Cavers (1903) recorded the occurrence of fungal mycelia in the sporogonia of Lophocolea bidentata, (L.) Dum., Radula complanata, (L.) Dum., Cephalozia bicuspidata, (L.) Dum., and Plagiochila asplenoides, (L.) Dum. In the last two, fungal hyphae have also been observed in the gametophyte (see below). According to Cavers, fungal hyphae enter the fertilized archegonium from above, grow down the neck-canal, and, in some cases, enter the venter and pierce the egg. Infected sporogonia in these instances were usually imperfectly developed and remained abortive. If the capsules matured the cavities were filled with a mass of interlacing hyphae in which were embedded numerous small spherical bodies abstricted from the hyphae, and therefore regarded as conidia.

Kny (1879) observed that the rhizoids of Marchantia and Lumularia were frequently traversed by fungal hyphae. These possessed crosswalls, and occasionally branched, but did not reach the thallus tissue, except in plants growing on rich humus, when they entered the thallus and ramified through it.

Stahl (1900) referred to the occurrence of mycorhiza in the Bryophyta. He considered that a real symbiosis may exist in the case of Calypogea Trichomanes, (L.) Corda, and in other Jungermanniaceae, as plants harbouring hyphae appeared to be larger than plants possessing none. $\mathrm{He}$ indicated that the presence or absence of fungal hyphae might be determined by the soil, as plants growing on soils rich in humus contained more hyphae than plants growing on other soils. Stahl suggested that an actual 
or a physiological shortage of water in the soil might lead to the presence of fungi in the thallus of Musci. Writing of the Hepaticae he connected the formation of starch in the thallus of the Marchantiaceae with a highly developed transpiratory organization and the complete absence, or at any rate meagre development, of a mycorhiza. In the case of the Jungermanniaceae he connected the formation of sugar in the leaves with low transpiratory activity and the extensive occurrence of mycorhiza. Since Stahl's paper was written, numerous examples of the presence of endotrophic fungi among the members of the Marchantiaceae have been recorded by Beauverie, Cavers, and Golenkin, and it is probable that the occurrence of fungi in the latter group is at least as frequent as in the Jungermanniaceae.

Beauverie (1902) described a fungus inhabiting the thallus of Fegatella conica, Corda. In this case the fungus produced both conidia and chlamydospores. Beauverie also suggested that a definite symbiosis existed, by means of which the life of the Fegatella plant became to a large extent saprophytic. Both in the plant and in cultures the fungus agreed closely with Fusarium.

Cavers (1903) described a fungus in the thallus of the New Zealand liverwort, Monoclea Forsteri. He found the fungus present in a sharplydefined zone of from two to four layers of cells in the thicker median portion of the thallus. The nuclei of the infected cells grew in size and became surrounded by tufts of short hyphal branches; the cells all contained chloroplastids, some of which also became surrounded by fungal hyphae. Large spherical vesicles, many of which had thickened walls, also occurred as in Fegatella. The fungus was not identified.

Golenkin (1902) described endotrophic mycorhiza in Marchantia palmata, Marchantia paleacea, Preissia commutata, Nees, Targionia hypophylla, L., and Plagiochasma elongatum, as well as Fegatella conica, Corda. The hyphae in all cases were confined to the compact ventral tissue. The cells retained their nuclei and cytoplasm but contained no starch or chlorophyll. Golenkin suggested that the function of the fungus in these instances was to store water, thus rendering the plants more resistant to drought. Cavers pointed out that Fegatella and Monoclea are both hygrophyllous forms, and therefore this hypothesis seemed improbable.

Fungal hyphae have also been observed in the vegetative organs of many of the foliose Jungermanniaceae, including Calypogea trichomanes, (L.) Corda, Lepidozia reptans, (L.) Dum., and Lophozia bicrenata, (Schmid.) Dum., by Němec; and in Scapania nemorosa, (L.) Dum., Diplophyllum albicans, (L.) Dum., Bazzania trilobata, (L.) Gray, Porella platyphyllum, Lindb., Cephalozia bicuspidata, (L.) Dum., and Plagiochila asplenoides, (L.) Dum., by Cavers. The two last also possess fungal hyphae in their sporophytes as noted above. 
Nermec (1899) identified the fungus in Calypogea trichomanes as an Ascomycete, Mollisia Jungermanniae. This fungus bore bluish-green apothecia, and covered the plant with a web-like mycelium. Where the mycelium penetrated the cells of the leaves or stem the cells lost their protoplasm and became discoloured.

Humphreys (1906) recorded the occurrence of tuberous swellings on the stem of Fossombronia longiseta which contained a fungus, but he neither described the fungus nor indicated its relationship to the plant.

Czapek (1889) stated that the tissues of Fegatella, Marchantia, and Lumularia contained an antiseptic substance, 'sphagnol', which existed in combination with the cell-walls and exerted an inhibitory influence on the growth of bacteria and moulds. Cavers has suggested the view that the sphagnol may serve to regulate the growth of the fungus, and to prevent symbiosis from passing into parasitism.

Coulter, Barnes, and Cowles (1911) referred to the occurrence of endotrophic fungi in mosses and liverworts, and various theories were mentioned by them to explain the significance of this symbiosis. They noted that in the Bryophyta fungal symbiosis seems to cause diminished rather than increased luxuriance and that probably the fungus alone is benefited.

W. G. P. Ellis (1897) described a disease caused by a fungus on Pellia epiphylla in the Botanic Gardens, Cambridge. The fungus produced a cobweb-like mycelium over the thallus and fructifications consisting of branched aerial conidiophores bearing clusters of round conidia. Septate hyphae resembling those on the outside of the thallus were also found in the cells of the plant, chiefly in the uppermost layers of cells, except in what are termed the 'rejuvenation shoots'. Cultures were made from spores removed from the spore clusters on the host, on nutrient gelatine; these grew to form mycelia which produced similar fructifications. Spores from these latter were used to inoculate the sterile apices (or rejuvenation shoots) of plants of Pellia epiphylla growing in the infected area, also other plants which were brought from a distance, and showed no trace of the disease. The spores put out germ tubes which penetrated the upper epidermis of the host and entered the interior. Ellis found that the fungus did not enter by the rhizoids, but only through the upper surface of the thallus. The walls of infected cells became brown, the protoplasm shrunken, the chloroplastids lost their colour and became massed together. Ellis identified the fungus as the conidial form of an Ascomycete, similar to, if not identical with, the Trichoderma-phase of Hypocrea. There are several important differences between the chief characteristics of the disease described above, and those of the subject of the present investigation. In the latter the fungus enters by the rhizoids, is present only in the lower portion of the thallus, and is never in the upper superficial layer or the one 
immediately beneath. No mycelium bearing conidia like those described by Ellis have been observed on the Pellia plants which have been used for the present paper; moreover, infected material remains quite green and appears perfectly healthy. It is therefore clear that Ellis was dealing with a fungus quite different from the one which forms the subject of this paper. He did not notice our fungus apparently.

H. E. Greenwood (1911), in a paper, 'Some Stages in the Development of Pellia epiphylla', described in great detail the structure and life-history of the plant, but no mention of the presence of any fungus was made.

\section{Distribution of the Fungus.}

\section{A. In the Gametophyte.}

Transverse sections of the thallus indicate that the fungus occurs only in the lower portion of the thickened central region.

The fungus is most easily seen in longitudinal sections of the thallus through the 'midrib', which, in this species, is normally from ten to twelve cells in thickness. The number of fungal hyphae present does not vary according to the habitat of the Pellia, but rather according to the degree to which the infection of the thallus has proceeded. As the plant is perennial this depends mainly on the season of the year.

In new growths branching from the thallus, only the rhizoids and lower epidermis contain the fungus; in older branches the two or three layers of cells adjoining the ventral surface as well as the rhizoids are infected, and in mature branches eight or nine layers of cells are inhabited by the fungus ; the upper two or three layers of cells, including the upper epidermis, remain free from hyphae. In one or two cases only the upper epidermis remained absolutely free of fungal hyphae-all the other cells were infected.

The hyphae apparently enter the thallus through the rhizoids. Two or more hyphae may pass up one rhizoid; in a few cases these show ladderlike fusions (cf. Němec, Calypogea trichomanes), but more often remain quite separate. Cross-walls occur at rather long and irregular intervals. The fungus branches as soon as it reaches the thallus, but sometimes not until it enters the layer of cells immediately internal to the lower epidermis. In the cells of the thallus the fungus branches freely, ramifies through the thallus, and extends to within about $2 \mathrm{~mm}$. of the growingpoint (Fig. I).

In some cells the ends of the hyphae become considerably swollen. These swellings occasionally occur also in intercalary positions, but they are usually terminal. They possess very granular contents, are thinwalled, and are probably merely swellings of the vegetative mycelium, which may be regarded as storage organs (Fig. I). Large spherical and in some cases oval-shaped bodies also occur on the hyphae (Fig. I). These 
are always terminal and possess very thick walls and granular contents, and measure $2 \mathrm{I}-28 \mu$ in diameter. They apparently correspond to the vesicles described by Cavers in Monoclea Forsteri, and by Beauverie in Fegatella conica. Beauverie regarded them as chlamydospores. This, in all probability, is their nature, as they occur in very large quantities in the old parts of the thallus - that is, in the portions which die off. As decomposition of these old portions of thallus proceeds, the spores may possibly enter the soil and germinate. In the plant, however, they have only been

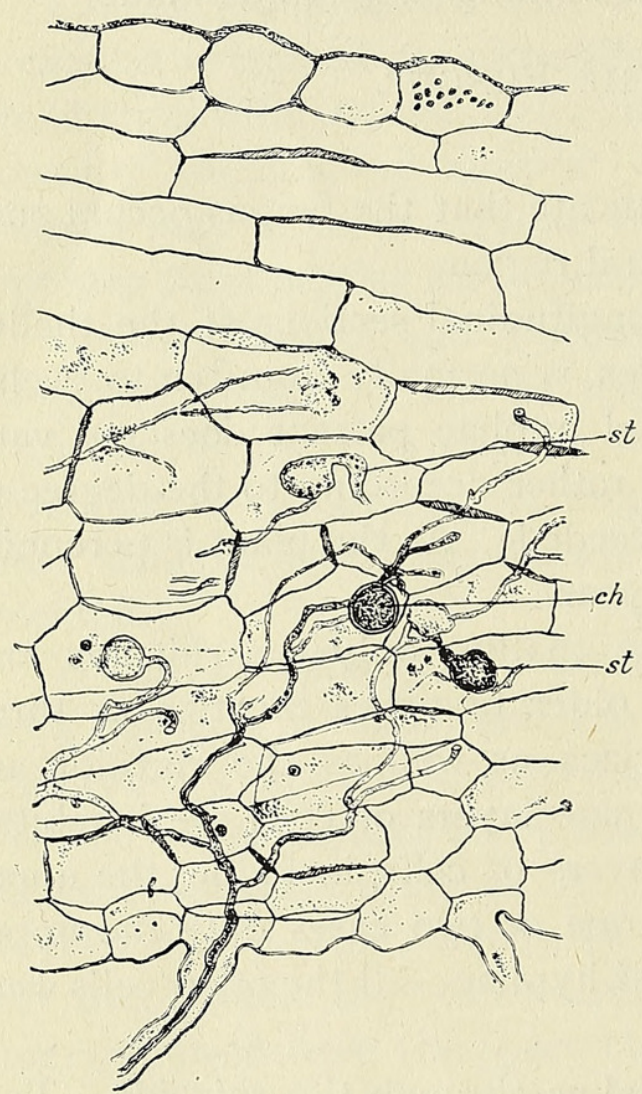

FIG. I. Longitudinal section of thallus through the thickened median portion, showing hypha from a rhizoid branching, ramifying through the thallus, and bearing storage organs and chlamydospore. X125. st., storage organ; ch., chlamydospore.

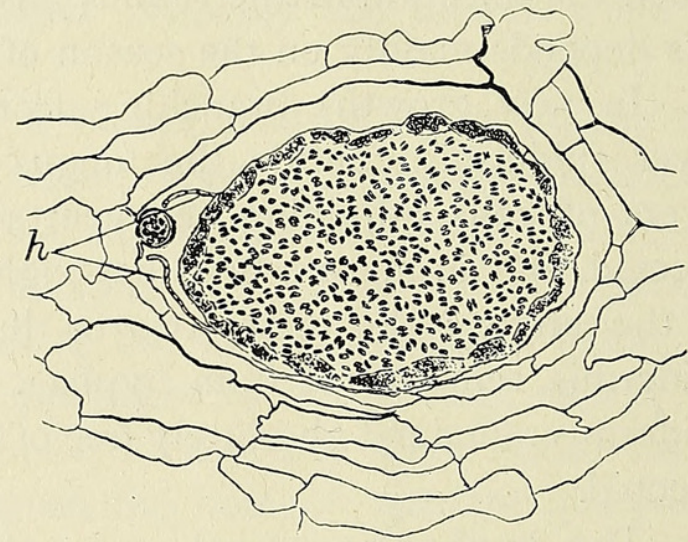

FIG. 2. Longitudinal section through the thallus, showing an almost mature antheridium with fungal hyphae around it. $\times 125$. h., hyphae.

observed in connexion with the mycelium, and in various attempts which have been made to isolate the fungus from the thallus they did not germinate.

The hyphae in the rhizoids vary to some extent in appearance. They may be very narrow, with thin walls, and constricted at short intervals, or they may be very narrow and thin-walled, but not constricted. These forms occur in the younger rhizoids. In older rhizoids the hyphae are much wider, with granular contents and thick walls which are often brown in colour (Fig. I). This is the normal condition for hyphae in the tissue of 
the thallus itself, where they measure from $5^{-7} \mu$ in diameter. In the younger branches of the mycelium the finer, thin-walled type occurs again. These hyphae measure $\mathrm{I}-4 \mu$ in diameter. The hyphae are very rarely constricted in the thallus except in the region of the antheridium (see below). In only one case have constricted hyphae been observed in the thallus.

In older plants heavily infected by the fungus, cells occur, dark brown in colour, in which the fungus produces curious structures somewhat resembling oogonia and antheridia. No further stages have been observed, however, and it is possible that they are merely indications of the hypertrophy of the vegetative mycelium.

In several cases the fungus has been observed in proximity to antheridia (Fig. 2). The fungus enters through the aperture of the

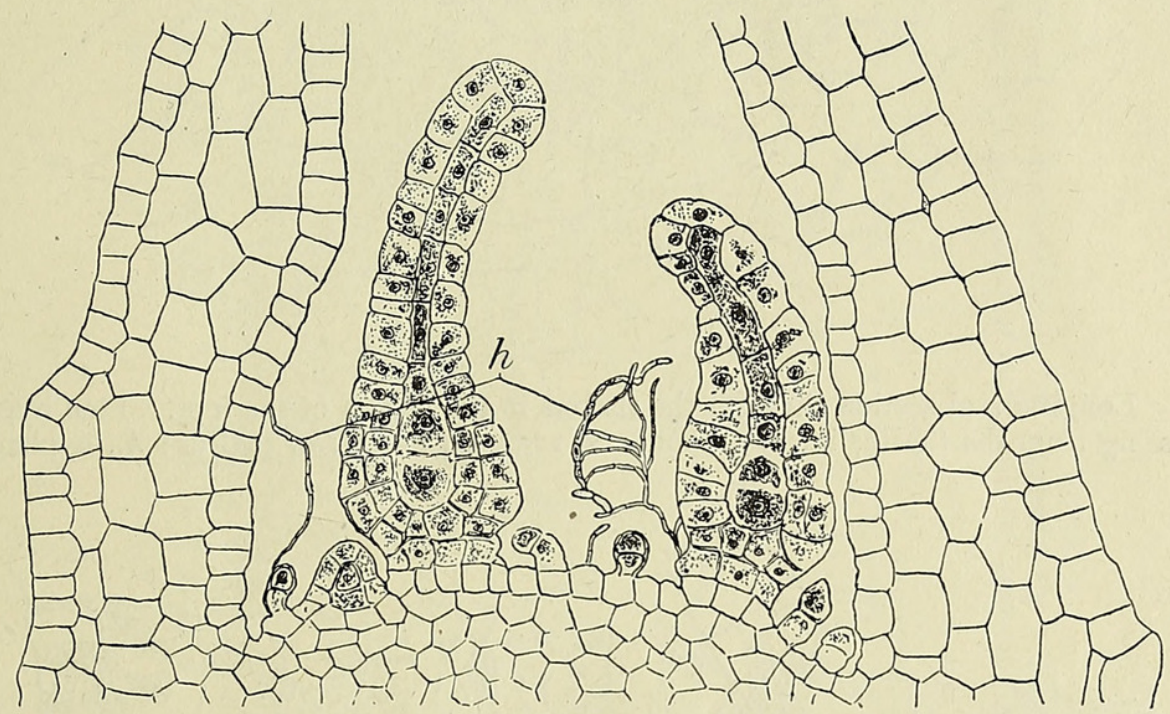

FIG. 3. Longitudinal section through the thallus with archegonia, showing fungal hyphae in close proximity to them. $\times \mathbf{1 2 5}$. h., hyphae.

cavity. No direct connexion has been observed so far between hyphae in the thallus and in the antheridium. The fungal hyphae in the latter are often constricted similarly to those in the rhizoids. When the antheridium is mature, and the antherozoids have escaped, the hyphae fill the empty antheridial cavity.

Fungal hyphae, similar to those around the antheridia, have also been observed near unfertilized archegonia (Fig. 3).

B. In the Sporophyte.

The fact that the fungus was present in the sporophyte was not observed for some considerable time. Normal healthy sporophytes were repeatedly examined, and no sign of the fungus was discovered in foot, seta, or capsule.

However, while the setae of the healthy sporophytes were elongating and the capsules dehiscing it was noticed that on other plants, much discoloured owing to extreme infection by the fungus, capsules were present 
which, instead of being the usual dark-green colour, were brownish-black, and moreover the setae of these did not elongate. On examining sections of this material it was found that the whole of the sporophyte as well as the thallus contained very great quantities of fungal hyphae. A series of sections showed that very fine hyphae penetrate from the thallus to the

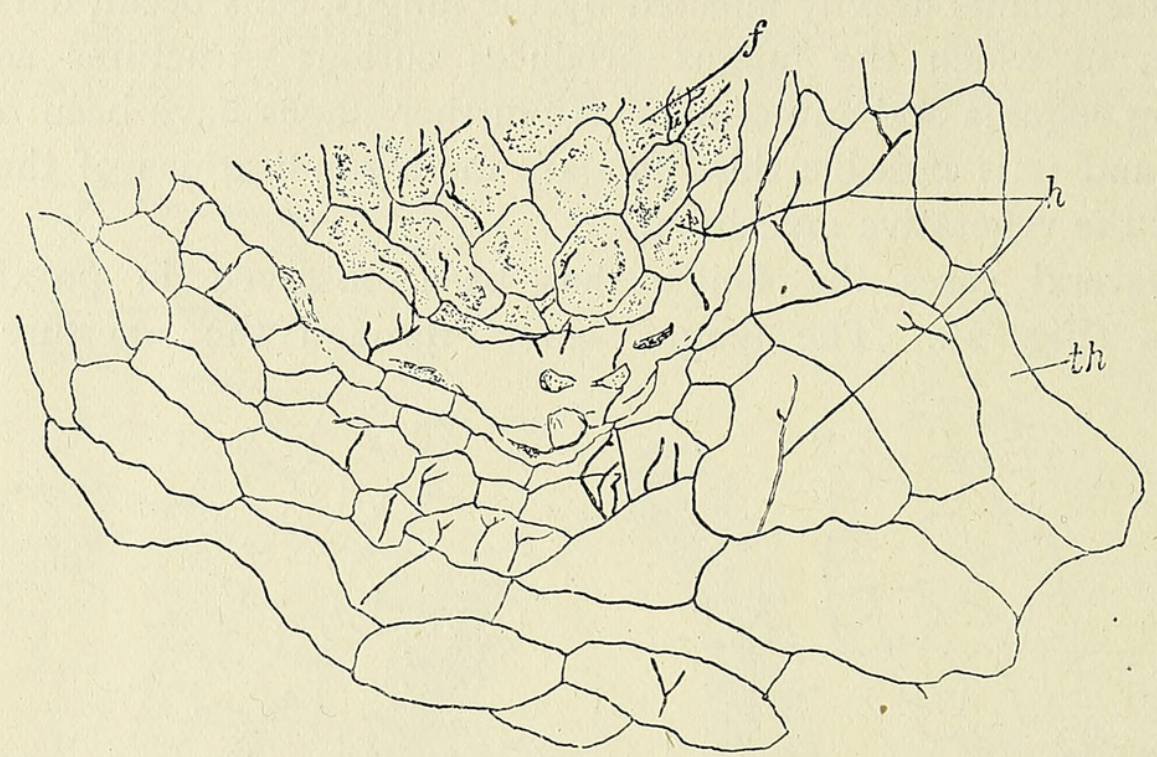

Fig. 4. Longitudinal section through the thallus in the region of the foot. Fine hyphae are passing from the thallus into the foot. $\times$ I $25 . f$., foot; th., thallus; $h$., hyphae.

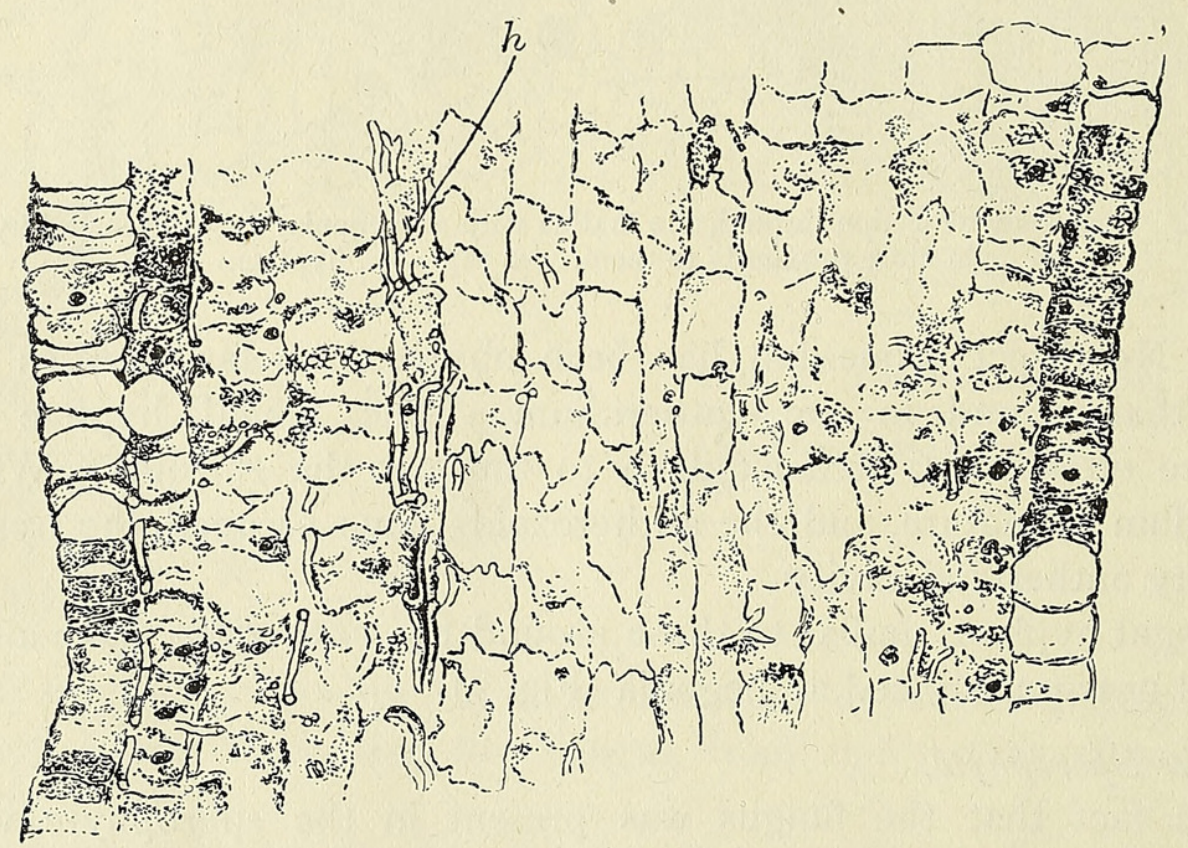

FIG. 5. Longitudinal section through the seta of an infected sporogonium. Some of the cell-walls are partially destroyed. $\times 167 . \quad h$., hyphae.

base of the foot (Fig. 4), and enter, ramifying through the tissue of this organ. The hyphae then pass up into the seta, where they become very much wider, possibly owing to the rich store of accumulated food material 
at their disposal (Fig. 5); they then enter the capsule (Fig. 6), ramifying between the young gametophytes and in some cases actually entering them (Fig. 7). There is also a considerable quantity of hyphae in the capsulewall, in the calyptra, and in the involucre.

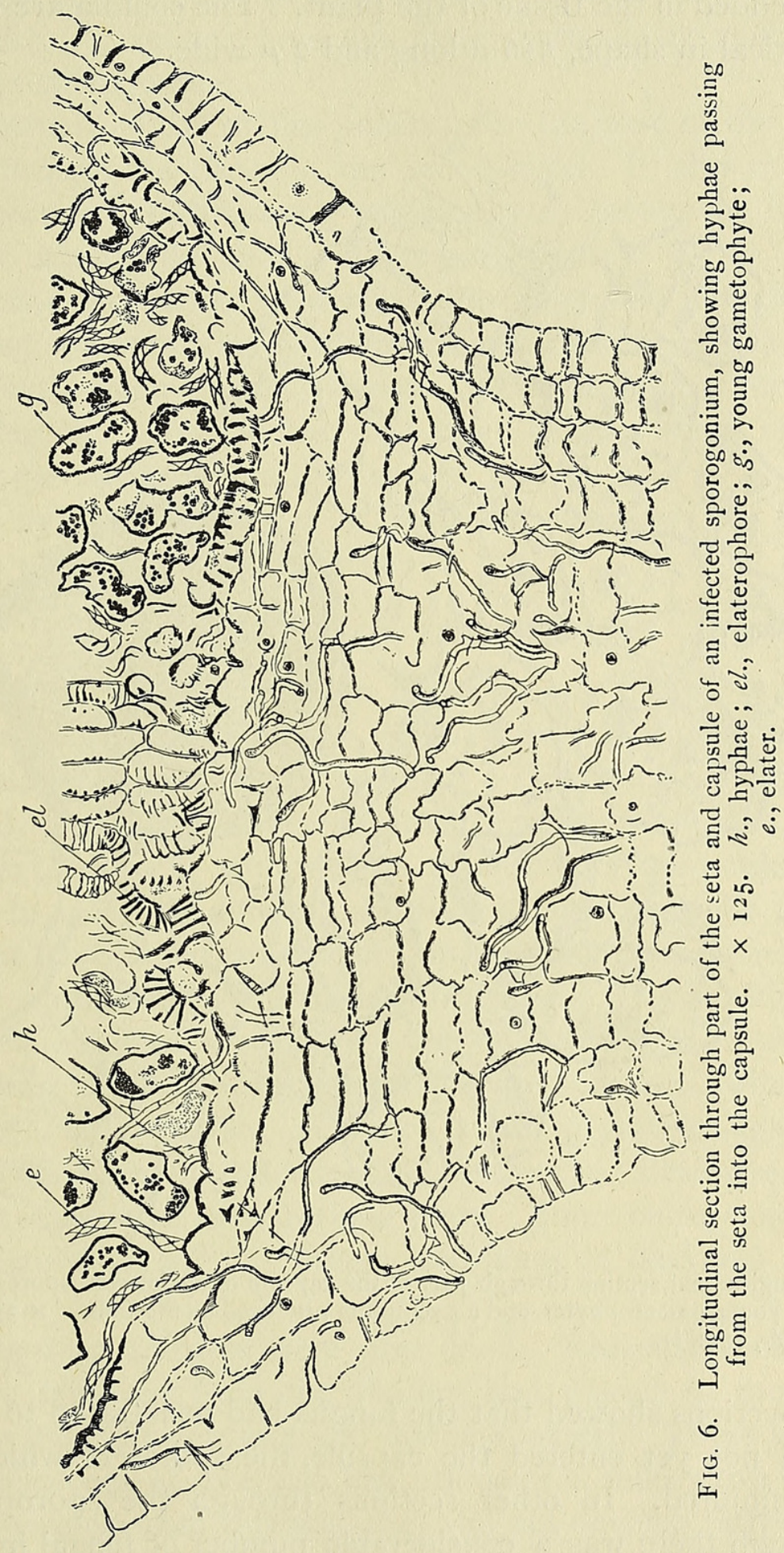

The hyphae in the sporophyte possess cross-walls at regular intervals, and the walls are not quite so thick as those of the usual type in the gametophyte; probably this also is due to the presence of the rich food 
store. On the capsule-wall, on the calyptra, as well as on the involucre, small pycnidia are produced containing numerous conidia (Fig. 7).

The pycnidia are from $80-120 \mu$ in diameter, smooth, globose, and open at the apex by a pore. They are completely or, more frequently, partially embedded in the tissue of the plant. The conidia are hyaline, onecelled, cylindrical in shape, $5^{-6} \mu$ long and $2 \mu$ wide.

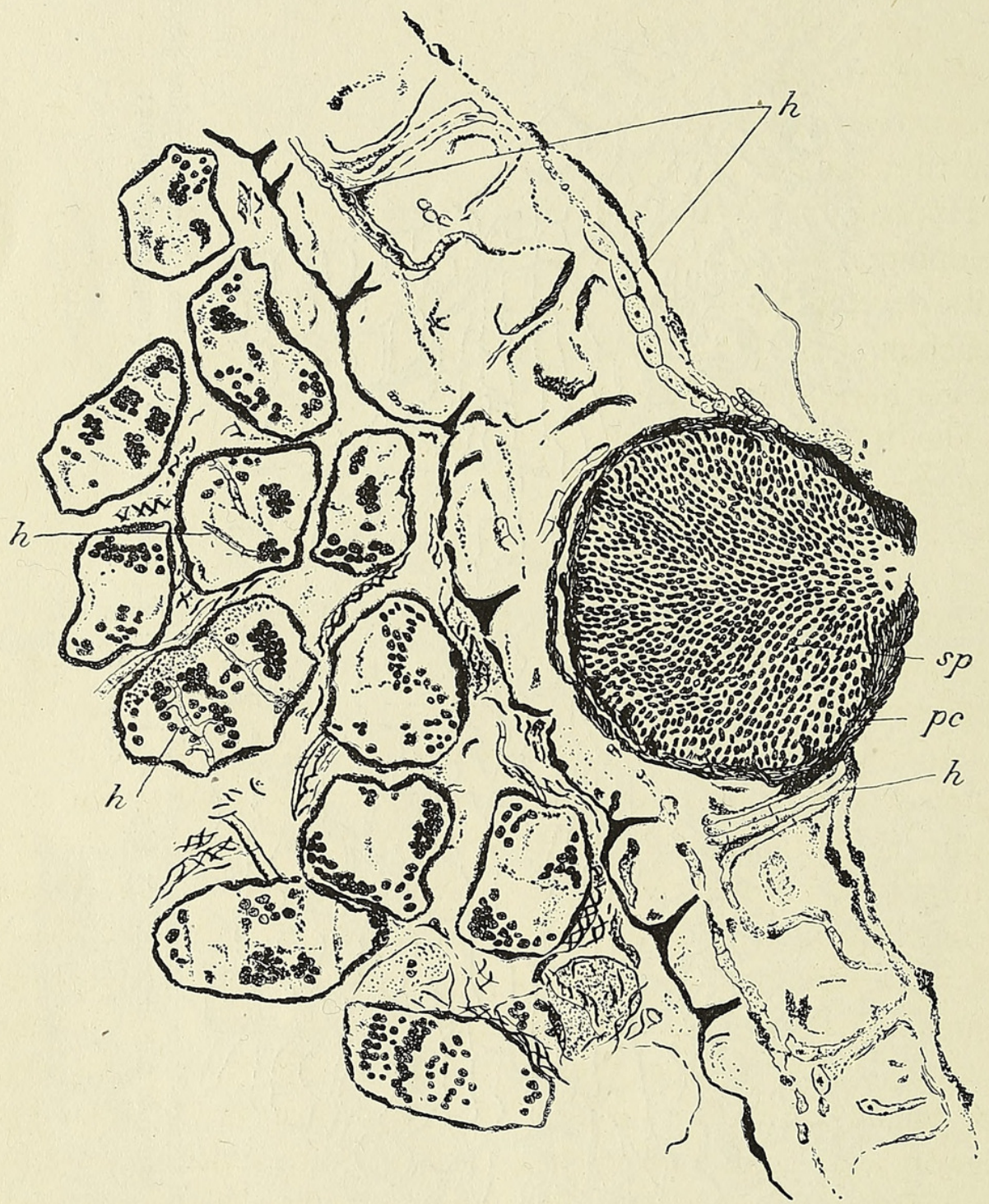

FIG. 7. Longitudinal section through part of the capsule of an infected sporogonium, showing hyphae inside the young gametophytes, and a pycnidium produced on the wall. $\times 333$. h., hyphae; $p c$., pycnidium; $s p .$, conidia.

Certain sections showed that the fungus had penetrated to the foot and seta, but had not yet entered the capsule, the spores of which were still green and uninjured. In other sections through the sporophyte it was seen that though there was a considerable number of fungal hyphae in the seta and capsule, and around the foot, there was none in the gametophyte thallus in the neighbourhood of the sporogonium. The capsules in such cases had not fully developed; the capsule-walls were not fully differentiated, 
the elaters had not developed spiral thickenings, and the spores had only reached the tetrad stage.

One sporogonium was found in a still more aborted form. In this case only a few divisions had taken place in the fertilized egg, which contained fungal hyphae, though there were none in the thallus near it.

Apparently, therefore, there are three methods by which the fungus may enter the sporogonium:

(a) Hyphae from the thallus penetrate to the base of the foot, enter it, and ramify through the tissue of the sporophyte. In this case the spores of the liverwort may form young gametophytes before the fungus obtains a hold on the capsule, but they will not grow farther.

(b) Hyphae may enter the fertilized archegonium and ramify through the developing sporogonium, which in this case remains abortive to a varying degree, its development ceasing almost at the beginning, the sporogenous tissue reaching the spore mother-cell stage or the tetrad stage-but the spores never germinate within the capsule.

(c) The hyphae may enter in both the above ways. Here, too, the sporogonium usually remains abortive.

\section{ISOlAtion OF THE Fungus.}

Repeated attempts were made to isolate the fungus from the thallus of the liverwort. Portions of the thallus were broken off, teased out with a sterilized platinum needle, sterilized in a 0.1 per cent. solution of mercuric chloride, and placed on plates containing various nutrient media. The fungus, however, did not grow. The experiments were repeated without sterilization in mercuric chloride solution, it being thought that the latter process might have killed the fungus, but no better success was obtained.

Various species of Penicillium, Eurotium, Mucor, \&c., as well as Bacteria were obtained on some of the plates in the latter case, whilst others remained sterile, but the endophyte was inactive. Meat agar, Pellia extract agar, Pellia extract gelatine, potato glycerine agar, malt agar, synthetic media with the addition of dextrose, or dextrose and peptone, and beerwort agar were used in these trials. Some cultures were incubated at a temperature of $23^{\circ} \mathrm{C}$. ; others were kept in darkness at room temperature.

Hanging-drop cultures were also tried. Rhizoids containing fungal hyphae were removed from the thallus, and placed in drops of various media (beerwort, Pellia extract, and distilled water). These were examined under the microscope at intervals, but, although in some cases fungal hyphae were seen emerging from rhizoids, they did not develop farther.

Upon the discovery of fungal hyphae and spores in the sporophyte, attempts were again made to isolate the fungus. Pieces of infected capsules were placed by means of a sterilized needle on agar plates. 
Within twenty-four hours the spores were germinating vigorously, and cultures of the fungus were obtained. These were reinoculated on various media.

\section{IDENTIFICATION OF THE FUNGUS.}

The fungus isolated in this way is a species of Phoma. It has not been found possible to reinoculate with it, as no Pellia without the fungus has been found. Attempts were made to propagate the Pellia alone from the sterile apices of plants, but without success. Young gametophytes of

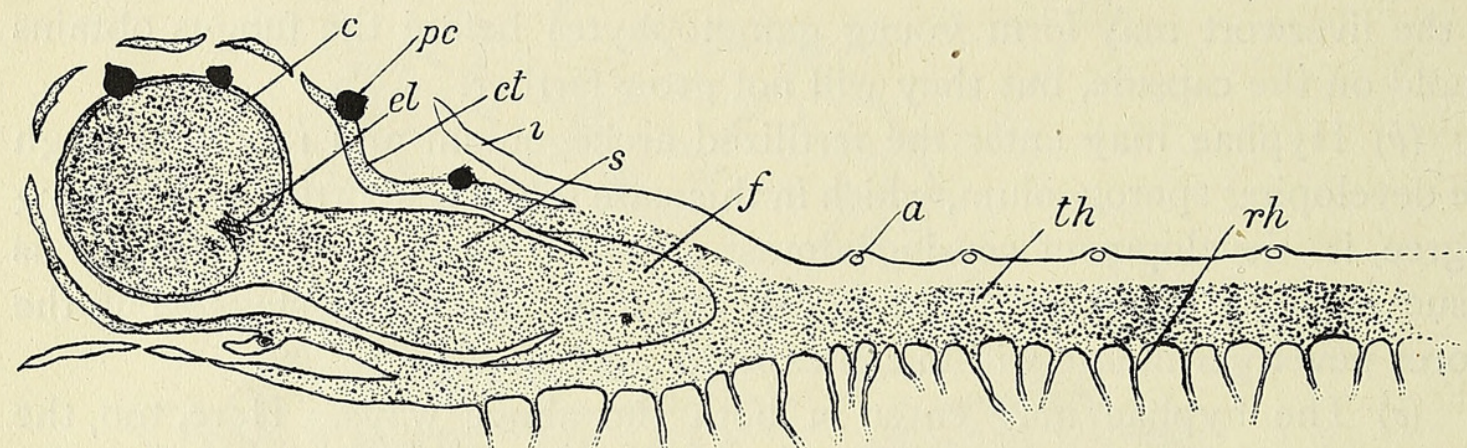

FIG. 8. Schematized drawing of a longitudinal section through the thallus and sporogonium. Shaded portion indicates the infected region. $\times$ I $5 . \quad c_{\text {. }}$, capsule; $p c$., pycnidium; $e l$., elaterophore; ct., calyptra ; $i_{\text {., }}$ involucre ; s., seta ; $f$., foot ; $a$. , antheridium ; th., thallus ; rh., rhizoid.

the liverwort have been placed under similar conditions, but did not develop to any extent.

\section{Physiological Relationships.}

The Gametophyte. The effect of the fungus on the tissue of the gametophyte is well marked. When first infected the cells of the thallus possess numerous chloroplastids and well-marked protoplasmic contents. As infection proceeds, the cells become brown and discoloured, and the chloroplastids disappear from all but the two or three layers of cells nearest the upper epidermis, which are free from the fungus. In a well-infected thallus the lower part becomes absolutely brown; the difference between this infected zone and the upper layers is, in some cases, very marked, the latter being still quite green and the contents of the cells uninjured.

The fungus in the brown zone is obviously in a flourishing condition, as are also the swollen vesicles. The cell-walls of the liverwort are apparently quite uninjured by the fungus, except at the point of penetration.

The presence of sphagnol in the cell-walls was tested for, but none was present. In this case there is therefore no evidence of an inhibitory influence exerted on the growth of the fungus, which may be the reason why it is able to obtain such a hold on the plant.

The relationship between the fungus and the gametophyte may be one of symbiosis. The apparently constant occurrence of the fungus in the 
thallus, and the difficulty of isolating it, point to such a relationship. The fungus evidently finds the liverwort a very favourable substratum, as indicated by the considerable number of fungal hyphae found in some material, branching profusely, and ramifying through the tissue in all directions, and obtaining food material from the cells into which they have penetrated.

The plant is to some extent unharmed - at least it can go on growing and reproducing in the normal manner. Whether the fungus is of any actual use to the liverwort is at present uncertain. Upon entering the thallus the fungus seems to sever its connexion with the soil, so that it is unlikely that the association is a mycorhiza.

Whatever may be the relationship, it seems probable that the fungus is the dominant partner, obtaining its food material from the liverwort, damaging it to a certain extent by killing the cells which it enters; but the liverwort, in most cases, still retains the power of growth and reproduction.

In a few instances, however, the association becomes of the nature of a disease. Here the cells are quite brown in colour ; the thallus in consequence, instead of appearing green, is dark brown, and incapable of further development.

The Sporophyte. In the sporophyte the effect of the fungus is much more drastic than in the gametophyte. The fungus has a twofold effect upon the tissues. The cells are turned brown in colour, the chloroplastids are destroyed, and the cells are ultimately killed. Secondly, the cell-walls partially disappear ; this is especially noticeable in the capsule-wall, where only the thickened walls of the cells are left whole, the thin walls being very indistinct or completely absent. The young gametophytes also are killed or prevented from reaching their full development. Their cell-walls are partially or completely absorbed, and the chloroplastids are discoloured, and all attempts to make them germinate, even when fully developed, have failed, whereas similar spores from healthy capsules germinated readily on a synthetic agar medium. Moreover, the whole tissue of the sporophyte becomes infected, as there is no definite zone which remains free of hyphae, as in the upper layers of cells in the gametophyte.

The cell-walls of the sporophyte did not respond to the test for sphagnol.

The relationship between the fungus and the sporophyte is obviously not one of symbiosis: in this generation of Pellia the fungus is a disease, killing the tissues and rendering them incapable of maturing.

\section{Summary.}

I. The cells of the thallus of Pellia epiphylla contain a fungus which occurs in a definite zone along the thickened median portion towards the ventral surface of the thallus and in the rhizoids. 
The fungus also occurs in proximity to the antheridia and archegonia.

2. In some cases the fungus is present in the cells of the sporophyte, where it may infect the whole of the tissues, sometimes rendering them abortive.

3. The fungus has been isolated from the sporophyte, and identified as a species of Phoma.

4. The effect of the fungus on the gametophyte of Pellia is very marked. The protoplasmic contents of the infected cells are killed, the chloroplastids disappear, and the cells ultimately become brown in colour.

The relationship existing between the fungus and the liverwort may be a symbiotic one; but the Phoma is probably the dominant partner and of little use to the Pellia-in extreme cases killing the latter, though usually it is able to grow and reproduce in the normal manner.

5. The effect of the fungus on the sporophyte is twofold. The contents of the cells are killed, and the cell-walls are also wholly or partially absorbed.

The relationship existing in this case is not symbiosis. The fungus causes a disease, killing the tissues of the sporogonium and in some cases rendering them abortive.

The courtesy of Professors Massart, Priestley, and Small, in providing material for this work, has been of great value in proving that the presence of the fungus in Pellia epiphylla is not restricted to a limited locality, but that it is normally present in plants obtained from such different sources.

I wish to express my sincere thanks to $\mathrm{Mr}$. C. Hunter, who suggested the subject of this paper, and whose constant valuable help and advice alone have made it possible to carry out this investigation.

I also wish to thank Professor O. V. Darbishire for his advice and interest in this work.

Cryptogamic Research Laboratory,

UNIVERSITY OF BRISTOL.

November I92I.

\section{REFERENCES.}

1. Beauverie, J.: Étude d'une Hépatique à thalle habité par un champignon filamenteux. Comptes rendus de l'Acad. des Sci. de Paris, 1902, p. 616.

2. Britton, E. G. : Fungi on Mosses. Bryologist, I91 I, vol. xiv, p. 103 .

3. Cavers, F. : On Saprophytism and Mycorhiza in Hepaticae. New Phytologist, 1903, vol. ii, p. 30 . 
4. Cooke, M. C. : Some Exotic Fungi. Grevillea, I889, 17; p. 76.

5. Coulter, J. M., Barnes, C. R., and Cowles, H. C. : Text-Book of Botany, I9I I, pp. 794 and 799.

6. Czapek, F. : Zur Chemie der Zellmembranen bei den Laub- und Lebermoosen. Flora, Band lxxxvi, I 889, p. $36 \mathrm{r}$.

7. Dunham, E. M. : Fungus Spores in a Moss Capsule. Bryologist, vol. xix, I9ı 6, p. 89.

8. Ellis, W. G. P. : On a Trichoderma parasitic on Pellia epiphylla. Journal of the Linnean Society, vol. xxxiii, I 897 , p. I02.

9. Fitzpatrick, H. N.: The Life-history, and Parasitism of Eocronartium muscicola. Phytopathology, vol. viii, 1918, p. 197.

10. Golenkin, M.: Die Mycorhiza-ähnlichen Bildungen der Marchantiaceen. Flora, Band xc, I902, p. 209.

11. Greenwood, H. E.: Some Stages in the Development of Pellia epiphylla. Bryologist, vol. xiv, I9I 1 .

12. Györffy, I.: Cladosporium herbarum on Buxbaumia viridis. Bryologist, vol. xiv, I9II, p. $4^{\mathrm{I}}$.

13. Humphreys, H. B. : Life-history of Fossombronia longiseta. Ann. Bot., vol. xx, 1906, p. 83 .

14. KNY and BöTTGER: Ueber eigenthümliche Durchwachsungen an den Wurzelhaaren zweier Marchantiaceen. Verhandl. d. botan. Vereins d. Prov. Brandenburg, I879. (Quoted from (3)).

15. LeitgeB : Untersuchungen über die Lebermoose, Heft 2, p. 58, I874-8I.

16. Levy, D. J.: Germination of Moss Spores on Agar. Bryologist, vol. xx, I9I7, p. 62.

17. Nawaschin, S.: Ueber die Brandkrankheit der Torfmoose. Bulletin de l'Acad. des Sci. de St. Pétersbourg, tome xxxv, I 892 , p. $53 \mathrm{I}$.

18. Ň̌mec, B.: Die Mykorhiza einiger Lebermoose. Berichte der deutsch. botan. Gesellsch., Band xvii, I 899, p. 3 I I.

19. Rayner, M. C. : Obligate Symbiosis in Calluna vulgaris. Ann. Bot., vol. xxix, p. 97.

20. Schimper, A. F. W.: Versuch einer Entwickelungsgeschichte der Torfmoose, i $85^{8}$, p. 54 .

21. Servattaz, C. : Développement et la nutrition des Mousses en milieux stérilisés. Ann. des Sci. Nat., Bot., vol. xvii, I9I3, p. I I I.

22. Stahl, E. : Der Sinn der Mycorhizenbildung. Jahrbücher für wissenschaftliche Botanik, Band xxxiv, I90o, p. 539.

23. WarnstorfF, C.: Zur Frage über die Bedeutung der bei Moosen vorkommenden zweierlei Sporen. Verhandl. d. botan. Vereins d. Prov. Brandenburg, I886. (Quoted in Revue Bryologique, I 887 , p. I 5.) 


\section{$2 \mathrm{BHL}$ Biodiversity Heritage Library}

Ridler, W. F. F. 1922. "The fungus present in Pellia epiphylla, (L.) corda." Annals of botany 36, 193-207. https://doi.org/10.1093/oxfordjournals.aob.a089793.

View This Item Online: https://www.biodiversitylibrary.org/item/234428

DOI: https://doi.org/10.1093/oxfordjournals.aob.a089793

Permalink: https://www.biodiversitylibrary.org/partpdf/319036

\section{Holding Institution}

Smithsonian Libraries

\section{Sponsored by}

Biodiversity Heritage Library

\section{Copyright \& Reuse}

Copyright Status: Not in copyright. The BHL knows of no copyright restrictions on this item.

This document was created from content at the Biodiversity Heritage Library, the world's largest open access digital library for biodiversity literature and archives. Visit BHL at https://www.biodiversitylibrary.org. 